\title{
COGNITIVE SCIENCE OF RELIGION, ATHEISM, AND THEISM
}

\author{
Myron A. Penner
}

\begin{abstract}
Some claim that cognitive science of religion (CSR) either completely "explains religion away," or at the very least calls the epistemic status of religious belief into question. Others claim that religious beliefs are the cognitive outputs of systems that seem highly reliable in other contexts, and thus CSR provides positive epistemic support for religious belief. I argue that (i) CSR does not provide evidence for atheism, but (ii) if one is an atheist, CSR lends "intellectual aid and comfort," (iii) CSR does not provide evidence for theism, but (iv) if one is a theist, CSR provides qualified support for Reformed Epistemology.
\end{abstract}

\section{Introduction}

Cognitive science of religion (CSR) is a multi-disciplinary research program that seeks to map and understand the cognitive systems that underwrite, generate, sustain, and transmit religious belief. While "religion" is notoriously difficult to define, cognitive scientists of religion tend to identify religious beliefs as those that are importantly related to belief in supernatural agents. Though not without its detractors, a common and influential model within CSR is the idea that belief in supernatural agents is the cognitively natural output of evolved cognitive processes that were selected for other purposes; typically, the relevant processes are some combination of Hypersensitive Agency Detection Device (HADD) and Theory of Mind (ToM). With a fine-grained brush, CSR paints a thoroughgoing naturalistic picture of religious belief. As a result, some have assumed that CSR either completely "explains religion away," or at the very least calls the epistemic status of religious belief into question. Others have argued that given the naturalness of religious belief as the cognitive outputs of systems that seem highly reliable in other contexts, CSR provides positive epistemic support for religious belief.

How should data from CSR influence the epistemic status of religious belief in general, or theism in particular? I will focus on the latter question: addressing the epistemological significance of CSR to theistic religious belief is the main subject of this paper. More specifically, I will argue for the following four claims: (i) CSR does not provide evidence for atheism, but (ii) if one is an atheist, CSR lends "intellectual aid and comfort," (iii) CSR does 
not provide evidence for theism, but (iv) if one is a theist, CSR provides qualified support for Reformed Epistemology.

\section{CSR and Atheism}

\section{I.A. Empirical Science, Testability, and Theism}

The relationship between theism and its empirical content is complex. Does theism have any empirical consequences? For Christian theists, the answer must be "yes." On one telling, the Christian narrative is of a God who creates and orders the natural world, brings creatures into being, including some who bear the imago dei, cultivates a community of followers from the dawn of civilization, and becomes incarnate in the person of Jesus of Nazareth through whom all things are being reconciled to God. This story, if true, entails minimally that there is a natural world, there are creatures, some creatures bear the imago dei, there has been a community of God-followers, and Jesus of Nazareth existed. One might be tempted to think that these simple empirical consequences of Christian theism are easily observable and thus provide some measure of empirical support for theism. But that would be mistaken in two respects.

Predictive Entailment. First, from some hypothesis $H$ predicting or making it likely that some event $E$ will obtain, and our observation that $E$ obtains, we initially don't learn very much about whether $H$ is true; this is because there could be some other hypothesis $H^{\prime}$ inconsistent with $H$ that also predicts $E$. What we do learn in this instance is our observation that $E$ hasn't falsified $H$. In order for our observation of $E$ to provide support for $H, E$ needs to be put in the context of alternative hypotheses. One way to do this is via inference to the best explanation (also known as abductive reasoning); another way is by applying what Elliot Sober calls "the Surprise Principle." ${ }^{1}$ Here's a relevant hypothetical example of abductive reasoning. Let $E$ be the event of Jesus of Nazareth existing, let $O$ in this case be a conclusive observational data set that makes the existence of Jesus on an epistemic par with the existence of, say, Abraham Lincoln, and let $H$ be the hypothesis of Christian theism along the bare lines sketched above. ${ }^{2}$ We can then form the following abductive argument:

1. We have the conclusive data set $O$-Jesus of Nazareth existed.

2. The best explanation for $\mathrm{O}$ is $\mathrm{H}$-i.e., that Christian theism is true.

3. Therefore, Christian theism is true.

As it stands, this isn't a very good argument. Even assuming that (1) is true, it's clear that (2) can be rejected. That's because in terms of explanatory

\footnotetext{
'Sober, Core Questions in Philosophy, 32-35.

${ }^{2} \mathrm{I}^{\prime} 1 \mathrm{l}$ assume also that $O$ doesn't include any alleged evidence with respect to miracles, resurrections, exorcisms and the like. Thus, by hypothesis $O$ supports only the claim that the human Jesus of the gospels was an historical figure.
} 
power with respect to this particular $O$, there's no advantage Christian theism has over myriad competing alternatives.

Another method for determining whether some observation $O$ supports one hypothesis $H$ over a competing hypothesis $H^{\prime}$ is by determining whether both conditions of the Surprise Principle are satisfied:

C1: If $H$ were true, $O$ would be expected.

C2: If $H^{\prime}$ were true, $O$ would be surprising. ${ }^{3}$

For ease of comparison let $O$ and $H$ remain the same as above, and let $H^{\prime}$ be the hypothesis that Christian theism is false. Here we can see that $\mathrm{C} 1$ is satisfied, but C2 is not, for if it turned out that Christian theism were false, making the observation $O$ (which you'll recall was the data set supporting the claim that the man Jesus was an historical figure) wouldn't be surprising in this case.

Auxiliary Assumptions. A second complication in determining whether some observation fits the empirical content of theism has to do with the crucial role played by auxiliary assumptions in generating testable observation statements for many theistic claims. Needing auxiliary assumptions to generate a testable observation is no mark against theism; many claims in science are only testable when embedded within a theoretical framework that employs assumptions at various levels. For example, we can test for the Higgs boson not because the claim "the Higgs boson exists" is testable all by itself. Rather, we can test for the Higgs boson only if we bring to the testing all sorts of assumptions about what the world is like and what the world would be like if the Higgs boson were to exist. But in order for an auxiliary assumption to be helpful in generating a plausible testable claim, the assumption should be less controversial and enjoy more epistemic support than the claim being tested. This is where things become tricky in employing auxiliary assumptions to get testable theistic statements.

Consider one claim from the Christian theistic story above: human beings bear the imago dei. What is the imago dei? How could we test for it? Suppose one held that the following assumption were true:

A1: A creature bears the imago dei if and only if it weighs more than 5 lbs.

If A1 were true, determining whether something bears the imago dei would be a straightforward procedure. But there's no reason to think that A1 is true; the challenge with many theistic claims is that the assumptions needed to generate testable observation statements are at least as controversial as the claim itself.

${ }^{3}$ For an in depth discussion of the inductive logic operative in scientific inquiry, see Sober, Evidence and Evolution, 1-108. 


\section{I.B. Potential Pathways of CSR Support for Atheism}

With this background, we're now ready to look at different ways that CSR-simplified and reduced to the claim that belief in supernatural agents is formed by natural processes that arose out of evolutionary mechanisms - could possibly provide support for atheism.

Theory Confirmation. On the assumption that CSR is true, one way CSR could provide support for atheism is if it could be shown that CSR is more probable on atheism than on theism. But utilizing the simple schemas discussed above with respect to the testability of theism, demonstrates that challenges similar to those faced by theists are also present when considering the relationship between empirical claims and atheism.

Let $A$ be atheism and $T$ theism. Now consider Sober's Surprise Principle. According to it, does CSR support $A$ over T? Recall the two conditions that must be satisfied if this is the case:

C3: If $A$ were true, CSR would be expected.

C4: If $T$ were true, CSR would be surprising.

C3 in this case has a measure of plausibility. For the most part, CSR provides a thoroughgoing and robust naturalistic explanation for many phenomena associated with religious belief. Unlike some other cognitive domains that really only make sense if the objects of cognition are real (e.g., physical objects in the case of sensory cognition), CSR provides a means of explaining why people believe in gods even if there are no gods. ${ }^{4}$ As an explanation of religious belief, CSR does have a certain degree of "fit" with atheism.

The problem, however, is with respect to $\mathrm{C} 4-$ what reason is there to think that it's true? In other words, what reason is there to think that if God existed, it would be surprising that belief in gods is formed as a spandrel of innate cognitive mechanisms? I see no plausible way of making that argument, because doing so will require at the very least conjoining auxiliary assumptions to theism that are at least as controversial as theism itself.

One might think that the Surprise Principle imposes a needlessly heavy burden on the atheist. "One doesn't need to show that CSR is surprising on theism," the atheist might protest. "Even if CSR were expected on theism, all that's needed is to show that the probability of CSR on atheism is greater than probability of CSR on theism." But the challenge here is that there's no non-circular, non-question-begging way of assigning probabilities where

\footnotetext{
${ }^{4}$ One might worry that, at least with respect to the traditional theistic view that God is a necessary being, the claim that CSR explains how people could believe in God even if there were no God, includes a necessary falsehood. This gets us into the realm of reasoning about counterpossibles, and while the semantic and interpretive issues are many and varied, there are various models for how this could work with respect to reasoning about God and gods. See Penner, "Personal Anti-Theism," 325-337; see also Davis and Franks, "Counterpossibles and the "Terrible' Divine Command Deity," 1-19; and Mawson, "On Determining How Important It is Whether or Not There is a God," 267-177.
} 
the probability of CSR on theism comes out lower than the probability of CSR on atheism.

Similar challenges arise when trying to frame CSR as support for atheism via abductive reasoning. Consider the following argument:

4. CSR is true.

5. The best explanation for CSR's being true is atheism.

6. So, probably atheism is true.

Even granting (4), this argument fails because there's no reason to think that (5) is true; theism can explain CSR equally as well as atheism, for one can easily cash out a theistic hypothesis that fits the CSR data as well as does an atheistic hypothesis. All else being equal, it seems that the pathway of theory confirmation doesn't hold much promise in using CSR to marshal support for atheism.

However, perhaps not all is equal between theism and naturalism with respect to explaining CSR. According to Jason Marsh, locating CSR's account of the cognition of supernatural agency within an evolutionary framework leads to a set of observations that are much more likely on naturalism than on theism. ${ }^{5}$ Consider the following observation:

$E^{*}$ : For a variety of biological, cognitive, and environmental reasons, early humans, including many anatomically and behaviorally modern humans, originally lacked a concept of God and were religiously restricted to concepts of limited, and sometimes mean, supernatural agents. As a result, many early humans, including many early anatomically and behaviorally modern humans, failed to believe in God or in anything like God. The nonbelief in question was both naturally occurring and nonresistant. ${ }^{6}$

With $\mathrm{E}^{*}$ so defined, Marsh goes on to present the following argument:

(P1) We know $E^{*}$ to be true (or at least $\mathrm{E}^{*}$ is very plausible).

(P2) Naturalism has much more predictive power with respect to $E^{*}$ than theism.

(P3) Naturalism starts out at least as plausible as theism (i.e., naturalism is at least as probable as theism independent of all evidence).

(C) So, other evidence held equal, theism is very probably false.

Marsh's (P2) is similar to (5) above, according to which atheism provides the best explanation for the truth of CSR. Marsh draws on CSR in order to flesh out $\mathrm{E}^{*}$, and he claims that philosophical naturalism, "the claim that no supernatural agents exist, that the world was not intentionally

${ }^{5}$ Marsh, "Darwin and the Problem of Natural Nonbelief," 349-376.

${ }^{6}$ Marsh, "Darwin and the Problem of Natural Nonbelief," 359. 
designed, and that nature is causally closed and morally indifferent to human beings and to their flourishing," ${ }^{\prime 7}$ provides a better explanation than theism for the fact that the supernatural agent concepts of early humans were not of the God of theism, but rather some other types of finite supernatural agents.

Defending (P2) requires both defending that (i) $\mathrm{E}^{*}$ is to be expected on naturalism, and (ii) $\mathrm{E}^{*}$ would be surprising if theism is true. I think that (i) is very plausible - that is, I think that given naturalism, it is reasonable to think that the CSR mechanisms underwriting supernatural agent beliefs in early humans and beyond involve many and varied types of finite supernatural agents. What about (ii)? Does theism make $E^{*}$ less likely than it is on naturalism? Marsh thinks so:

Given naturalism's commitment to indifference about whether early humans would be theists, and given that a perfectly good God would desire to enter into a divine-human relationship with early humans, naturalism makes $\mathrm{E}^{*}$ comparatively much more likely than theism. Again, God might have reasons that we can't imagine for permitting $E^{*}$, as so-called skeptical theists will point out. But again, it is no less likely that God has reasons that we can't imagine for never permitting $\mathrm{E}^{*}{ }^{8}$

Marsh seems to be appealing to intuitions about what we should expect God to do if God were a familiar sort of agent.

Consider, for example, Sue, the city planner for fictional Metro City, who values the contribution that parks and green spaces make to the overall quality of life for the city's residents. In fact, Sue would go so far as to say that it was important for her that citizens had easy access to multiple parks. Suppose also that while the quantity of, and accessibility to, park space in Metro City is directly a function of Sue's say-so, it turns out that park space in the city is very rare and hard to get to. In this case, we'd be justified in claiming that Sue is not a very good city planner. The case of Sue can serve as an analogy for how Marsh is assessing theism. One might wonder, as Marsh seems to, that if God exists, and having a divine-human relationship is important to God, why is belief in a theistic God not a significantly more natural product of the biological, cognitive, and social factors that have shaped human beings from our evolutionary past and into the present? God by definition can't be a bad planner, but by observations similar to the sort we made of Sue, certainly seems to be one. If Metro City's park space were the product of a good city planner who valued park space, the facts on the ground would look much different. And similarly, one might think, if it were important to God that human beings believed in a theistic God, wouldn't God make it more natural biologically, cognitively, and socially to believe in such a God?

Recall that what we're after here in assessing Marsh's argument is whether naturalism has greater predictive power theism with respect

${ }^{7}$ Marsh, "Darwin and the Problem of Natural Nonbelief," 351.

${ }^{8}$ Marsh, "Darwin and the Problem of Natural Nonbelief," 359. 
to $E^{*}$. The first condition of Sober's Surprise Principle has been satisfied in comparing naturalism to theism as explanatory hypotheses for the natural, non-resistant belief in finite supernatural agents-this is pretty much what one would expect if naturalism is true. But is $\mathrm{E}^{*}$ surprising on theism, thus satisfying the second condition of the Surprise Principle and therefore providing a reason to think that naturalistic atheism is true?

There are two different ways for theists to respond here. The first way is to claim that, ultimately, we don't have a good way of assigning the likelihood of $\mathrm{E}^{*}$ on theism, in which case, we don't really know whether theism fares better or worse than naturalism as an explanation of $E^{*}$. Such a move would be consistent with a trajectory within Christian theism that has tended to emphasize the cognitive distance between creator and creature. Long before "skeptical theism" became a term of art in contemporary philosophy of religion, theists have wondered how and in what way human language about God could refer to God. That is, theologians have long wrestled with the epistemological consequences of the ontological gap between God and creatures. So, while Marsh claims that the following likelihood is true:

$$
\operatorname{Pr}\left(E^{*} \mid \text { naturalism }\right)>\operatorname{Pr}\left(E^{*} \mid \text { theism }\right)
$$

one theistic move is to claim that because we don't know how likely $E^{*}$ is on theism, we've no plausible way of judging whether the right comparison of likelihoods is $>,<$, or $=$.

However, this sort of skeptical refuge isn't a very satisfying response. It would be better for the theist if there were some principled way of cashing out a theistic hypothesis (i.e., not ad hoc, consistent with traditional theism, etc.) according to which $\mathrm{E}^{*}$ is at least just as likely as it is on naturalism. As discussed in section I.A above, in order for theism to generate testable observation statements, theism must be conjoined with auxiliary statements. And the challenge facing Marsh is similar to the (often unacknowledged) challenge theists face when pointing to some empirical claim as evidence for God's existence: needing some controversial auxiliary assumption to be true in order for the empirical claim to count the way the person making the observation thinks it does. Marsh needs to assume that God is relevantly similar to Sue the city planner in order to defend (P2), and he does note that on a traditional theistic account, the God of perfect-being theology would lovingly "desire to enter into a divine-human relationship with early humans." ${ }^{\prime \prime}$ But the further auxiliary assumptions that are required in order for $\mathrm{E}^{*}$ to be more likely on naturalism than theism are assumptions of the following sort:

AA1: Early humans had no divine-human relationship with the theistic God.

${ }^{9}$ Marsh, "Darwin and the Problem of Natural Nonbelief," 359. 
But different and principled auxiliary or background assumptions are available to theists. For example, consider the following:

AA2: Humans, including early humans, are immortal and have a cognitive life that survives their bodily death.

AA3: God is able to relate to creatures who lack accurate or complete God concepts.

AA4: God could use evolution as the mechanism by which divine image bearers are brought about. ${ }^{10}$

Assuming AA2-AA4 gives the theist a different set of resources with which to assess the likelihood of $E^{*}$ on theism. Let's look at each of these assumptions in turn.

Conjoining AA2 to theism allows for the possibility that early humans, while having no initial concept of a theistic God, eventually were capable of acquiring the theistic God concepts that according to Marsh would be required for a loving God to enter into divine-human relationships. Is AA2 a reasonable assumption for theists, qua theists, to make? It certainly seems so-the continued cognitive existence of persons beyond their death is part of various theistic accounts of human persons.

AA3 is also reasonable for theists to assume. If something like AA3 were not assumed, it would be impossible for God to relate to creatures at all. This is because as an infinite being, a complete or entirely accurate set of God concepts is beyond creaturely cognitive grip. So, in order for God to enter in to loving relationship with creatures, there must of necessity be some conceptual accommodation on God's part to allow for the cognitive distance between creature and creator.

What about AA4, the assumption that evolution is a means by which God could bring about creatures who bear God's image? It's worth noting that some of Darwin's earliest defenders included Christian theologians and scientists who were Darwin's contemporaries and had no reservations about thinking of divine creation along evolutionary lines. ${ }^{11}$ True, not all theists endorse AA4, but as long as there has been evolutionary theory, there have been theistic evolutionists.

Now, with AA1-AA4 in hand, the predictive power of theism with respect to $E^{*}$ changes quite a bit. Given AA4, it makes perfect sense that God concepts would evolve over time. In fact, it would be surprising if early humans had a set of God concepts qualitatively very similar to the concepts employed by humans much later in evolutionary time. But given AA3, early humans lacking complete or accurate God concepts would be no barrier for divine-human relationship, and given AA2, there'd be no limit on the time available for humans to have their cognitive and

\footnotetext{
${ }^{10} \mathrm{I}$ 'm making no assumption here about "guided mutations" or cataclysmic divine interventions in evolutionary processes.

${ }^{11}$ See Livingstone, Darwin's Forgotten Defenders.
} 
conceptual array they utilize in relating to the divine to be shaped and enhanced over time.

In order to assess the predictive power of naturalism and theism with respect to $E^{*}$, one needs to conjoin certain auxiliary assumptions to theism in order to determine how theism fares in comparison with naturalism. Marsh, for example assumes that a loving theistic God would want relationship with humans, including early humans, but also assumes AA1 according to which early humans had no loving relationship with God. But as we've seen, there are a whole slate of auxiliary assumptions within theistic reach according to which the cognitive portrait painted by CSR and evolutionary psychology of the religious life of early humans is pretty much what one would expect.

Unreliability Arguments. The pathway of theory confirmation promised to be a direct path from CSR to atheism, but proved to be a dead end. This section and the next explore whether there are more productive routes from CSR to atheism via less direct paths. One such indirect route is via some sort of unreliability argument. In brief, an unreliability argument attempts to show that because some particular way of forming beliefs is error-prone, one therefore has a defeater for accepting the outputs of that way of forming beliefs. And on one sort of analysis, the cognitive mechanisms that support religious belief do seem incredibly unreliable. They produce wildly divergent and inconsistent outputs-the religious landscape is many and varied. But one doesn't need CSR to show that; one just needs to look around. What does CSR add to the observation of religious pluralism such that taken together, they provide evidence for atheism?

One might think that CSR provides a nuanced and empirically supported model that explains why we shouldn't expect the reliability of the mechanisms that produce belief in gods. Because religious belief is a by-product of systems selected for other purposes, we shouldn't expect them to be reliable in those spandrel domains-that we have religious beliefs at all is held to be an evolutionary accident. However, this line of reasoning is fraught with problems, many of which concern the relationship between reliable faculties, truth, and adaptive value. To be sure, there is no necessary connection between adaptive belief (and the systems that generate adaptive belief) and true belief. But there's no necessary disconnection, either.

Granting that it's logically possible that an adaptive cognitive system can yield unreliable outputs, or that a reliable cognitive system be nonadaptive (either adaptively neutral or even maladaptive), one might ask: isn't it just unlikely that a system with no adaptive value could be reliable? ${ }^{12}$ And if it turns out that religious belief itself isn't adaptive, but merely a by-product of cognitive mechanisms selected for other purposes, then we'd have an undermining defeater for the outputs of these beliefforming processes.

${ }^{12}$ This question was posed by an anonymous reviewer. 
A lot here turns on how one "counts" cognitive systems, and how one measures the degree to which outputs of some system contribute to an organism's ability to survive and reproduce. But setting aside those complications, think, for example, about the cognitive systems that underwrite abstract and theoretical reasoning in science. In addressing the question of whether one can give an evolutionary account of abstract rationality, Elliott Sober observes the following. ${ }^{13}$

This question imagines there to be a split between those techniques for processing information which have some practical consequences for survival, and those techniques which are central to "pure" science and thereby have no impact on reproductive success. If this were a correct way to partition the organism's inferential equipment, then there indeed could not be selection for the methodology of science. But from this it does not follow that the methodology could not have emerged because of natural selection. Pleiotropy is a familiar phenomenon within evolution; a single gene combination may be responsible for two phenotypic traits, only one of which is selected for. The other trait gets carried along for the ride, as it were. This free rider may be neutral, or even deleterious in impact on the organism's overall fitness. So even if there were a real distinction between "practical" techniques of inference and "purely theoretical" ones, this would not block an evolutionary account of theoretical method. ${ }^{14}$

This description, then, gives a plausible scenario in which we have a cognitive apparatus that is both reliable-as reliable as abstract scientific reasoning is, suitably qualified-but not adaptive per se. This supports my earlier claim that, structurally, the adaptive value and the degree of reliability are distinct features for cognitive systems that may or may not correlate. Even if it turns out that religious belief is not adaptive, that doesn't entail that religious belief forming mechanisms are therefore unreliable.

It is sometimes said that evolution is blind to truth-but it's more accurate to say that evolution is blind to truth-values; natural selection is blind to both truth and falsity. Cognitive systems are selected for in virtue of their adaptive value; some systems will be reliable (perhaps because reliability contributes to adaptive value, perhaps not), and some systems will be unreliable (perhaps because unreliability contributes to adaptive value, perhaps not). And what's true of cognitive systems with respect to their being selected for evolutionary purposes is also true of any cognitive spandrels. Again: there's no necessary connection between spandrels and true belief; but there's no necessary disconnection, either. So, even if one were to grant the unreliability of religious belief-forming mechanisms, it is difficult to see how CSR explains that unreliability in a way that would provide evidence for atheism.

\footnotetext{
${ }^{13}$ Sober, "The Evolution of Rationality," 95-120.

${ }^{14}$ Sober, "The Evolution of Rationality," 99-100.
} 
But isn't there something of use to the atheist in pointing out what seem to be the "wildly divergent outputs" of the cognitive processes that underwrite religious beliefs? Doesn't CSR and widespread religious diversity provide some sort of argument for atheism? Matthew Braddock has argued that, if not providing evidence for atheism, CSR plus the widespread diversity of religious beliefs should cause monotheists to suspend judgment about the outputs of the mechanisms that give rise to religious beliefs. ${ }^{15}$

Braddock's detailed and interesting paper presents a two stage argument. In the first stage, he argues that monotheists should suspend judgment about the reliability of the CSR mechanisms that underwrite and support god beliefs. This is because monotheists, in virtue of their monotheism (hereafter I'll just use "theists") must acknowledge that the mechanisms that give rise to god beliefs in the vast majority of cases, have generated false god beliefs. In the second stage of the argument, Braddock acknowledges that CSR mechanisms by themselves are not solely responsible for god beliefs - rather, they are embedded within a host of other contributing factors for god beliefs, including sociocultural influences. Could these other contributors correct for the underlying unreliability of CSR mechanisms? According to Braddock, absent independent evidence that these other contributors do correct for the unreliability of CSR mechanisms, we should suspend judgment about the overall reliability of the entire belief-forming process for god beliefs, a process to which unreliable CSR mechanisms are a significant contributor. The ultimate conclusion of Braddock's two-stage argument is that no god belief is justified, absent independent evidence for it. Has Braddock shown, contra to what I am claiming in this section, that CSR provides evidence for atheism, at least to the degree that it demonstrates that theism is unjustified? By my lights, he has not.

For ease of analysis, I'm going to simplify Braddock's two-stage argument into a single unreliability argument that utilizes the central premises and inferences to which Braddock is appealing. Let "CSRM" stand for the common belief forming processes that generate god beliefs, and let " $\mathrm{O}$ " stand for factors other than CSRM that influence god beliefs. So understood, Braddock seems to be claiming the following:

(i) Theists must hold that CSRM are massively unreliable.

(ii) Theists have no evidence that $\mathrm{O}$ corrects for the unreliability of CSRM.

(iii) One should suspend judgment about outputs of a belief-forming process that is deemed massively unreliable and not corrected for.

(iv) Thus, theists should suspend judgment about the reliability of CSRM and are not justified in accepting some output of CSRM (absent independent evidence for that output).

${ }^{15}$ Braddock, “Debunking Arguments and the Cognitive Science of Religion," 268-287. 
Before considering the premises of Braddock's argument, it's worth pointing out the limited scope of unreliability arguments in providing evidence for atheism. Even if Braddock's argument is sound (though I'll argue below there are good reasons to reject its premises), at most this would mean that CSR provides some evidence for agnosticism, not atheism. All that would be commended by the conclusion of Braddock's argument, if sound, is that theists should suspend judgment about the reliability of the cognitive mechanisms that underwrite their intuitive religious beliefs, and if they are honest inquirers, look to see if there is independent evidence that factors other than innate cognition (socio-cultural factors, theistic arguments, etc.) that support either theism or atheism. But even granting Braddock's argument, we can see that CSR falls short of providing evidence for atheism.

With respect to (i), Braddock claims that theists must claim this because being committed to the truth of theism entails holding that any god belief incompatible with theism is false. And seeing as how the vast majority of god beliefs that have been held going back to human pre-history have been incompatible with theism, theists must acknowledge that CSRM are massively unreliable. Here Braddock is holding a very tight connection between a cognitive mechanism typically generating false beliefs and that mechanism being unreliable. However, this fails to account for two alethically relevant properties - namely, the properties of approximating truth and entailing truth.

What is it for a belief to be approximately true? The concept of approximate truth has played a prominent role in discussions in philosophy of science and the realism/anti-realism debate. Realists in philosophy of science claim that the success of science is good reason to think that scientific theories are true, or approximately true, descriptions of the world, even at the level of unobservable entities. Thus, even while technically false or incomplete in some respects, a theory can be taken as approximating truth if there's a sufficient degree of accuracy in the theory to do so. And when it comes to CSRM, a theist is perfectly within her epistemic rights to hold that CSRM, while technically delivering false beliefs, may in fact be delivering outputs that approximate truth in important respects-particularly when the outputs attribute divine agency to events that the theist would also agree are a function of divine agency. True, the theist is committed to the polytheist having a false belief, but she could also hold that there's something about the polytheist's belief that approximates truth.

This brings us to the second alethic property that is relevant to assessing (i) of my reconstructed argument of Braddock: the property of entailing truth. It is often the case that false propositions entail true propositions such that false belief can be a pathway, via inference, to truth. For example, suppose you walk through your living room and see an unlit candle on the coffee table in front of the sofa. Suppose also that five minutes later you re-enter the living room and now you see that the candle is lit. You immediately form the belief that Bob lit the candle. You also infer that you 
are not alone. It turns out that Bob didn't light the candle-it was Sue. But your belief that you're not alone is true. And that true belief that you're not alone is sufficient to justify all sorts of rational behaviors. Now, a theist can have a similar view towards CSRM with respect to their degree of reliability. A theist can without contradiction agree with Braddock that, technically, CSRM have delivered false beliefs in the vast, vast majority of cases. But that doesn't make them completely useless from an alethic perspective. For it could be that in important contexts they deliver outputs that (a) approximate truth in important respects or (b) entail true propositions that justify all sorts of religiously relevant and rational behaviors. Thus, the theist can deny (i) if "massively unreliable" means "of no alethic significance."

Moreover, judgments about the reliability or unreliability of any cognitive system will need to take into account factors of context and scope. For example, sensory cognition may be highly reliable in some contexts (good light, close distances, no mind-altering drugs, etc.), but highly unreliable in other contexts (poor light, long distances, etc.). It could be that the operation of agency detection and theory of mind in the religious domain, spandrel though it may be, is in fact highly reliable in producing beliefs of a certain kind. Suppose naturalism is false, and that there is a domain of existence that transcends the material-religious cognition seems pretty reliable at generating or supporting beliefs like that. ${ }^{16}$

Return now to Braddock's central claim that because the vast majority of outputs for CSRM have thought of supernatural agency in terms of polytheism, theists must hold that CSRM are massively unreliable. However, I've argued that, conceptually, theists can view the operations of CSRM among polytheistic religions throughout history and into the present as having a certain kind of alethically relevant reliability, even while technically delivering false outputs. This is because false beliefs can still approximate truth in significant ways, and it can also entail true beliefs that are religiously significant. It's beyond the scope of this paper to explore in any great detail how this would go for the CSRM outputs of polytheistic religions, but there are resources in research on the history of religions that suggests a framework for further research along these lines.

In his article "Monotheism and Polytheism," Jan Assmann traces an historically informed conceptual framework for analyzing polytheistic religions and notes their conceptual continuity and discontinuity with different types of monotheisms. ${ }^{17}$ According to Assmann, the first-century

\footnotetext{
${ }^{16}$ Murray, "Scientific Explanations of Religion and the Justification of Religious Belief," 168-178; Murray and Goldberg, "Evolutionary Accounts of Religion," 179-199; Barrett, Cognitive Science and Theology, 131-132. Also relevant here is that cultural scaffolding can account for much religious diversity, and Barrett's work seems to show a significant degree of cross-cultural unity with respect to the outputs of religious cognition; he identifies and defends thirteen common cross-cultural non-reflective religious beliefs, such as immaterial agent causation and divine omniscience.

${ }^{17}$ Assmann, "Monotheism and Polytheism," 17-31. Assmann's typology for theological themes in polytheistic religions are drawn from Roman, Greek, Egyptian, and Babylonian
} 
BCE scholar Varro identified a helpful three-fold theological framework for Roman and Greek religion that also fits Egyptian and Babylonian religion. This, says Assmann, demonstrates "that we are dealing here with a rather general structure of polytheism." 18 This general structure sees divine activity manifested in three main spheres: cosmologically the gods are involved in creating and sustaining the created order, politically the gods are involved and integrated in civic social structures, and mythologically the gods are agents in historical narrative events that have explanatory value. Assmann sees an historical development of polytheism with a hierarchical structure in the pantheon (with an emphasis on "high gods"), to belief in a supreme being (the Highest God), to belief in one God-this is dubbed "evolutionary monotheism," and it expresses a religious outlook deemed to be "the final stage of polytheism." In contradistinction to polytheism, "evolutionary monotheism," emphasizes the falsity of other gods and the reality of the one true God, and the perils of worshipping false gods. Revolutionary monotheism further subdivides into "evidence-based" and "revelation-based" types, depending on how one acquires justified belief in the monotheistic God.

Now suppose that Assmann has correctly identified a general structure of polytheistic religions (and this would need to be confirmed on a caseby-case basis). If so, it would be plausible to also suppose that it's common for adherents of polytheistic religions to affirm as the outputs of CSRM (or via inference from those outputs) the following: the natural order is a created order, the divine cares about human social structures, and a true and complete explanation of history must include divine agency. Those are all CSRM outputs (or inferences from those outputs) that theists can affirm. In varying ways, then, theists can look at the CSRMs operative in polytheistic religions and see that while tuned by culture and circumstances in ways that deliver false outputs, other alethically relevant features of CSRM allow the theist to tell an epistemically respectable story-one that is fully aware of the epistemic shortcomings of CRSM-along the following lines:

Yes, CSRM in the vast majority of cases deliver beliefs that are, technically, false. But, from a theistic perspective, it seems that even these false beliefs point to, or approximate, truth in some important respectspointing to the reality of the supernatural, for example, and leading to a view of the self as more than a mere collection of matter. Moreover, the false outputs of CSRM could entail many propositions - religiously significant propositions - that theists think are true. The fact that the entailment was generated by a false belief may not be as significant as the proposition that's entailed by the false belief.

In sum then, with respect to Braddock's unreliability argument, we can see that even if sound, it does not provide evidence for atheism - at most it

polytheisms.

${ }^{18}$ Assmann, "Monotheism and Polytheism," 18. 
would licence agnosticism. But moreover, we can see that the line between divergent polytheistic CSRM outputs and a theistic commitment to their unreliability is not as straightforward as Braddock suggests. Paying attention to other alethically relevant properties and conceptual continuities between polytheistic and monotheistic religions undermines Braddock's premise (i), that is, that theists must hold that CSRM are massively unreliable.

Ontological Irrelevance Arguments. Earlier I said that "CSR provides a means of explaining why people believe in gods even if there be no gods." This is because, on the model of CSR we are considering, one can easily imagine a possible world $W$ like the actual world in every relevant respect and such that no God or gods exist in that world, and yet the phenomena of belief in supernatural agency in $W$ looks exactly like it does in the actual world. ${ }^{19}$ For CSR, the existence of the object(s) of religious belief in no way factors into the explanation of why those beliefs arise in the first place. And this could be an indirect way in which CSR lends evidential support for atheism, provided that something like the following argument is sound:

7. On CSR, a subject's belief in supernatural agents requires no causal connection to supernatural agents.

8. S's justified belief in some $X$ requires $S$ 's being causally connected to $X$ in the right way.

9. So, CSR shows that belief in supernatural agents is unjustified.

While (8) is an epistemological principle that some will find controversial because of its externalist leanings, my comments will focus on two ways by which (7) can be rejected..$^{20}$

It should be noted that successful natural theology would negate (7). ${ }^{21}$ For example, a successful cosmological argument would establish that God's existence is necessary for the existence of any contingent minds, including those contingent minds that believe in supernatural agents. Or a successful fine-tuning argument would establish that God's existence is necessary for explaining why we live in a universe conducive to life at all. Thus, if these natural theological arguments are successful, (7) is false, because subjects having beliefs-indeed the existence of contingent subjects at all-requires certain kind of causal connection to God: the creator/

\footnotetext{
${ }^{19}$ Murray, "Scientific Explanations," 168-178.

${ }^{20}$ In brief, externalist epistemologies locate epistemic justification in processes that can function apart from the subject's internal awareness that the justifying conditions obtain. This is contrasted with internalist epistemologies which hold that a subject's internal awareness that justifying conditions obtain is necessary for justification. For a good introduction to the internalist/externalist debate, see Lemos, An Introduction to the Theory of Knowledge, 108-130. For a more in depth description and defense of externalist justification, see Bergmann, Justification Without Awareness.

${ }^{21}$ Murray, "Scientific Explanations," 175-176.
} 
creature connection. ${ }^{22}$ Obviously, the natural theology response to ontological irrelevance arguments is successful only to the degree that natural theology is successful. And while the best natural theology should give illinformed and non-reflective atheists pause, theistic arguments (including cosmological arguments and arguments from cosmic fine-tuning) tend to have an "escape hatch," and rely on a premise or inference that can be rationally rejected if one is sufficiently informed about a host of relevant philosophical factors, costs, and benefits. ${ }^{23}$

However, a different way of rejecting (7) and one that doesn't require endorsing natural theology is to adopt-as many do-a common-sense, fallibilist epistemology. To explain this response, recall Descartes's evil demon and consider the possibility that we are just brains in jars having mental images fed to us by an evil demon whose chief goal is to feed us with false beliefs. Notice that there is a parallel between what the atheist is saying concerning CSR and what the global skeptic is saying about sense perception: both scenarios involve mass deception and license widespread skepticism concerning the outputs of a particular domain of cognition.

But most of us (epistemologists included) don't think we're brains in jars, or that we're being fed mental sensations and images by an evil demon-even though there's no way of proving that this is not the case. Instead, non-skeptical philosophers tend to help themselves to two principles which, taken together, provide a plausible way of resisting global skepticism:

Fallibilism: $S^{\prime}$ s knowing that $p$ is consistent with its being logically possible (but not actual) that $S$ is mistaken with respect to $p$.

Common Sense-ism: If S's belief that $\mathrm{p}$ is common and undefeated, then it is justified.

Fallibilism provides non-skeptical philosophers a basis for entertaining the possibility of one's knowing some proposition $p$ even if - as is the case on a demon hypothesis - it is logically possible that one is mistaken with respect to $p$. Common sense-ism provides non-skeptical philosophers a basis for the justification of the sorts of beliefs that global skepticism was said to undermine. Taken together, the epistemological burden of proof shifts to the skeptic.

What our discussion of Fallibilism and Common Sense-ism shows is that (7) is ambiguous in a way that is relevant for determining whether (7) is true or can do the work it needs to as a premise in an argument for atheism. Recall the claim:

\footnotetext{
${ }^{22}$ Again, it's not the specific belief content for which the causal connection is required if some natural theology is successful-it's the existence of minds at all which are necessary for forming beliefs.

${ }^{23}$ See also van Eyghen, “Two Types of 'Explaining Away' Arguments," 966-982.
} 
7. On CSR, a subject's belief in supernatural agents requires no causal connection to supernatural agents.

Now compare (7) to $\left(7^{\prime}\right)$ :

7'. On a demon scenario, a subject's belief that she has hands requires no causal connection between the subject's belief and her hands.

According to the fallibilist, the sense of "requires" in $\left(7^{\prime}\right)$ should be understood as "logically requires," but because, on fallibilism, knowing that $p$ is consistent with the logical possibility (but not actuality) of being mistaken concerning $p,\left(7^{\prime}\right)$ does nothing to defeat one's justified belief that one has hands. A similar option is available for the fallibilist concerning (7); consider $\left(7^{\prime \prime}\right)$ :

$7 "$. On CSR, a subject's belief in supernatural agents requires no causal connection to supernatural agents - that is, it's logically possible for a subject to believe in a supernatural agent even if no such agent exists.

But if one has justified belief in supernatural agents, ( 7 ") does no more to undermine justified belief in the supernatural agent case than $\left(7^{\prime}\right)$ did in the case of global skepticism.

However, one might wonder if the cases of external world skepticism and supernatural agent skepticism are really parallel. ${ }^{24}$ For example, one could object to my analogy and hold the following:

The demon scenario outlines a mere logical possibility whereas CSR has a stronger empirical basis and at the very least is assumed to be true in order to consider its philosophical implications. So we are not faced here with the mere possibility that we could forming a belief without the right causal connection. We are faced with a theory that says that we would (probably) form such a belief, whether or not the right causal connection existed. And this suggests that the mechanisms responsible for god beliefs, are not truth-sensitive, whereas we've no similar reason to doubt sensory faculties. ${ }^{25}$

However, this line of response makes two crucial assumptions. First, this objection assumes that one can make a justified inference from an ontological irrelevance claim to a negative existential claim - that is, from observing that one doesn't need the existence of Xs in order to believe there are $\mathrm{Xs}_{\mathrm{s}}$ (the ontological irrelevance claim), one is able to infer with justification that there are (probably) no Xs (negative existential claim). Second, the objection assumes that this inference from ontological irrelevance to a negative existential claim is appropriate in the god belief case but not in the sense perception case. It is far from clear that one should grant the first

${ }^{24} \mathrm{My}$ thanks to an anonymous reviewer for pressing this point.

${ }^{25}$ This scenario is adapted from comments from an anonymous reviewer. 
assumption. A significant theme in the epistemological literature on global skeptical scenarios at least since Descartes is that ontological irrelevance is pervasive and extends to the common world of everyday objects, but that negative existential claims about objects of perception don't necessarily follow. ${ }^{26}$ However, even if we grant the first assumption about whether the inferential move is justified -it will be difficult to outline a distinction between the domain of supernatural agent beliefs and the domain of sensory beliefs in an epistemically neutral, non-circular way. ${ }^{27}$

Matthew Braddock makes essentially the same point in his "Debunking Arguments and the Cognitive Science of Religion." Braddock discusses an argument from the insensitivity of god beliefs (essentially, an epistemological version of the ontological irrelevance argument). The crucial premise, and one that Braddock ultimately rejects, is:

(D4) If the processes that produce our basic beliefs are insensitive, then we should suspend judgment about their reliability, in the absence of independent evidence for their reliability.

Braddock rejects (D4) for reasons similar to those I offered in rejecting (7) above: namely, mere awareness of insensitivity isn't sufficient for doubting reliability:

Yes, awareness of insensitivity plus the fact that the relevant worlds are nearby would give us reason to doubt reliability. However, worlds where there is no necessarily existing God (if such a God exists) are impossible worlds, and so are not relevant to assessing the reliability of our belief in such a God. To successfully make the case that accessible insensitivity entails a debunking conclusion, the debunker would have to show that a world without a necessarily existing God is a nearby world; and it is entirely unclear how the debunker could show that without relying on the question-begging assumption that there is no such God..$^{28}$

So, it turns out that neither ontological irrelevance nor insensitivity to truth provide reasons for rejecting the outputs of CRSM's.

Paying attention to ontological irrelevance and alethic insensitivity, we can note that for any belief, we can distinguish between the cognitive circumstances that gives rise to the belief and the facts on the ground that make the propositional content of the belief true or false. And for nearly any belief there will be cognitive circumstances such that if the belief were formed in those circumstances, the belief would be insensitive to truth. In that respect, the observation of insensitivity by itself is uninteresting: it applies too broadly. What's needed in order to make the objection hold is an additional support for the world-specific circumstances that give rise to the belief in question. As Braddock notes, with respect to theism, that will involve assuming that God, a necessary being, does not exist-an as-

\footnotetext{
${ }^{26}$ See also Thurow's “Does Cognitive Science Show Belief in God to be Irrational?," 77-98.

${ }^{27}$ See chapter 3 of Alston's Perceiving God.

${ }^{28}$ Braddock, “Debunking Arguments," 284.
} 
sumption that one won't want to make if one is looking to CSR to provide evidence for atheism.

Summary. CSR, it turns out, does not provide evidence for atheism. It provides no religiously-neutral empirical support for atheism such that CSR is more probable on atheism than on theism. Atheism neither best explains CSR, nor is CSR the kind of observation we should find surprising if theism is true. Moreover, attempts to utilize CSR in service of unreliability, ontological irrelevance, or alethic insensitivity arguments for atheism are also unsuccessful. Judgments of reliability and unreliability need to factor in scope and context, and it could be that while perhaps unreliable in some contexts (narrow scope), religious cognition is reliable in other contexts (wide scope). With respect to the ontological irrelevance of supernatural agents to belief in supernatural agents, according to a fallibilist, common sense perspective, the logical possibility of being mistaken with respect to $p$ does nothing to defeat the justification of one's belief that $p$.

\section{I.C. CSR and Intellectual Aid and Comfort for Atheism}

This is not to say that CSR is of no use to atheists. If one already is an atheist, CSR can yield a bit of existential security by providing what I call "intellectual aid and comfort."

Undermining Some Religious Claims. For example, CSR does undermine some claims that could be made by religious believers. Suppose one held:

10. Widespread belief in gods is proof of some underlying, supernatural reality.

If one is an atheist, one can take comfort in the possibility provided by CSR that gods are ontologically irrelevant to belief in them. According to CSR, widespread belief in gods is evidence for underlying, natural cognitive processes that are geared towards accepting supernatural agency-nothing more.

Similarly, suppose one holds, as many religious believers do, something like:

11. The best explanation for my sense that God did X is that God did X.

This "best explanation" style claim shouldn't cause atheists any anxiety, in part because CSR provides an empirically informed alternative explanation for one's attribution of divine agency behind some phenomenon $X$. CSR provides a model according to which one's sense of divine agency in the world could be the product of entirely natural cognitive processes, and so much more work would need to be done in any particular case to show that the supernatural explanation of $X$ really is to be preferred to a naturalistic CSR interpretation of $X$.

Worldview Coherence. Another thing CSR provides atheists is a few strands that can be used in the quest for a coherent web of belief. CSR is a robust explanatory framework for why people believe in gods. CSR explains why this belief is pervasive, cross-culturally recurrent, and very difficult to 
dislodge. And while religious claims may not be impervious to truth, CSR shows how these pervasive beliefs at least may be held without requiring the underlying reality of the domain they are allegedly about. All this, I claim, should provide the atheist with some intellectual comfort. It would be troubling, intellectually, if given the rise of cognitive science there were was nothing like a remotely plausible natural theory of religion. But there is, so the atheist needn't be troubled in that respect.

However, and this is a key point often overlooked by atheists who seek to use CSR in service of atheism, this "aid and comfort" only arises if one already is an atheist. CSR fits with certain things that atheists hold to be true and/or desire to be true-that should provide some comfort. However, CSR also fits with certain things that theists hold to be true and/or desire to be true. Intellectual aid and comfort is not the same as evidence.

\section{CSR and Theism}

\section{II.A. Naturalism, Atheism, and Theism}

Much of the preceding discussion concerning whether CSR supports atheism is also relevant for determining whether CSR supports theism. Moreover, one might wonder whether there are pathways of CSR support for theism parallel to the ones we considered for atheism: are there good arguments to show that CSR confirms a theistic hypothesis, requires the reliability of faculties that give rise to religious beliefs, or ontologically requires the existence of supernatural agents?

The prospects for using CSR to support theism along any of these lines are not good. I've already noted some of the challenges in using empirical observations as evidence for theism and atheism-particularly with the needed role for auxiliary assumptions and the difficulty in coming up with assumptions that are both independently plausible and can generate testable predictions. Theism fares no better than atheism when trying to support it as the best explanation for the data of CSR or in terms of the probabilistic reasoning captured in the Surprise Principle. Moreover, data from CSR certainly doesn't seem sufficient to support a new type of abductive argument where God's existence would be the best explanation of why we have religious beliefs. What about "reliability arguments"? Does CSR, contra common atheistic appropriations of the data, support theism by undermining atheism due to the reliability of our faculties that produce belief in gods?

Justin Barrett and Ian M. Church have recently argued along those lines, suggesting that CSR, while not establishing theism per se, does undermine the epistemic plausibility of atheism. Barrett and Church argue that, given the vast majority of people who believe in at least one god, the minority position of the atheist is akin to the person in a nightclub who is perplexed when all her friends remark how many attractive people there are in the club, when she herself has reached the opposite conclusion. Her confusion is alleviated when she realizes that her friends have consumed 
alcohol at the club which tends to cause the inebriated to view others as more attractive than they would otherwise seem - her friends are wearing their "beer-goggles" which impairs their judgment and causes them to make unreliable judgments. Similarly, the atheist might reason that people who believe in gods have impaired belief-forming faculties (BFFs) which results in their having false beliefs about the supernatural. Barrett and Church go on to assess whether the beer-goggles analogy is a sufficient defense against the epistemic pressure atheists should feel as a result of their minority position.

Barrett and Church adopt a standard model of CSR, according to which (i) religious beliefs in the existence of one or more gods, a soul, an afterlife, are cognitively natural, (ii) the cognitive faculties supporting religious belief is part of "general conceptual toolkit-not some religion specific faculty," and (iii) these faculties incline toward, but don't guarantee, religious belief. They go on to argue that the atheist's beer-goggles defense is not strong given the dis-analogy between the beer-goggles case and the BFFs that yield these core religious beliefs: while we have clear evidence that alcohol impairs faculties, we have no such evidence that religiously tuned BFFs are so impaired. And as with all arguments via analogy, there's always the worry about whether one has judged an appropriate similarity or considered all the relevant factors in the scenarios being compared-more evidence may always come to light. For example, in the beer-goggles case, there might be special circumstances that cause alcohol consumption in this case to increase, and not decrease, faculty reliability; or there might be special circumstances that cause the sober person to have unreliable faculties - an abundance of false positives doesn't entail complete unreliability, with beer-goggles and assessments of beauty, or with BFFs that generate belief in gods. Moreover, given the standard CSR model that the BFFs supporting religious beliefs are part of our broader conceptual toolkit, they argue that skepticism about their outputs in the religious domain entails a much broader skepticism about their deliverances in other areas.

On Barrett and Church's view, atheists should feel epistemic pressure that comes from holding a minority view and shoulder an explanatory burden to demonstrate that their minority position is defensible in the face of their disagreeing with the vast majority of humankind concerning the existence of at least one god..$^{29} \mathrm{CSR}$, on their view, adds to the atheist's burden through CSR's picture of religious beliefs as cognitively natural and part of a broader conceptual toolkit. The naturalness of religion and its being produced by faculties we typically take to be reliable in other domains means that the BFFs that yield religious beliefs can be dismissed only if one is willing to pay the price of a deep and pervasive skepticism about our cognitive faculties more generally. If Barrett and Church are correct, then CSR, while not supporting theism directly, does provide indirect

\footnotetext{
${ }^{29}$ Barrett and Church, "Should CSR Give Atheists Epistemic Assurance?," 311-324.
} 
support for theism by undermining the plausibility of atheism. But have Barrett and Church successfully shown that CSR undermines atheism?

In my view, they have not. Barrett and Church's argument seems to utilize the following epistemological principles:

Credulity: Absent defeaters, we are prima facie justified in accepting the deliverances of our faculties.

Majority: The vast majority's believing $p$ is good evidence for $p$.

Uniformity: BFFs are reliable or unreliable uniformly - that is, they are reliable or unreliable across relevantly similar domains.

Anti-Skepticism: Deeming the BFFs that produce religious beliefs as unreliable entails a broad, unwelcome skepticism about the BFFs more generally.

Notice, however, that as an epistemic principle, Credulity cuts both ways and is available to the atheist as well. The atheist who finds herself believing that the world lacks supernatural agency would, via Credulity, have prima facie justification for her belief. Barrett and Church claim that the standard model of CSR either defeats this prima facie justification (because we should think that the BFFs that produce religious belief are typically reliable) or leads to skepticism about the reliability of the BFFs that are responsible for belief in the supernatural (and for a host of other belief-domains as well).

Let's consider the first horn of this dilemma: that CSR can defeat prima facie justification for atheism. In order to defeat the atheist's prima facie justification for her atheism, Barrett and Church utilize something like Uniformity, and locate the burden of proof on the atheist to show that belief in the supernatural is relevantly dissimilar to "beliefs about human minds (including conscious beliefs, desires, emotions, and their relationship to actions), the causal properties of the natural world, and so on." ${ }^{30}$ If the atheist cannot show that belief in gods is relevantly dissimilar to belief in, for example, the mental states of others and the connection between mental states to actions, etc., then she is obligated to accept the reliability of the BFFs that typically produce belief in supernatural agents. She has thereby acquired a defeater for whatever prima facie justification she may have for her atheism. However, decisions about burden of proof are complex, both with respect to whether and to what degree one bears such a burden, as well as to what counts as sufficiently having met that burden. How could the atheist describe the domain of supernatural agency as being relevantly dissimilar to other domains that fall within the range of the same BFFs without being guilty of ad hoc "special pleading"? ${ }^{31}$ It seems like the atheist who tells the following sort of story has sufficiently

\footnotetext{
${ }^{30}$ Barrett and Church, "Should CSR Give Atheists Epistemic Assurance? 316.

${ }^{31}$ Barrett and Church, "Should CSR Give Atheists Epistemic Assurance? 316
} 
met the burden of supporting the relevant dissimilarity between supernatural agent beliefs and other outputs of religious BFFs:

When it comes to Sue's believing, say, that Bob is angry on the basis of Bob's facial expressions, and Sue's believing that Bob's being angry is what caused him to punch the wall-cases like that are qualitatively different than, say, Sue's believing that a god is pleased with her on the basis of her sense that a god is pleased her (maybe because Sue just finds herself with the sense that this is so, or because she infers that this is so based on her experiencing some material blessing), even if the beliefs in either case are produced by the same BFFs. Bob-cases are different from god-cases for the simple reason that Sue can directly see Bob. And Sue can't directly see gods, if there are any. When Sue sees a Bob-filled region of space-time arranged a certain way (furrowed brow, clenched teeth) and sees Bob moving through space-time such that he strikes the wall with his fist, Sue just has much stronger support for her belief that Bob is angry and that his anger caused him to punch the wall than she does for her belief that a god is pleased with her. Partly this is due to the fact that, ontologically, Bob is similar to all sorts of other beings (e.g., Bill, Mary, and John) who, on occasion give facial clues that indicate anger and act in ways that suggest that their anger is a causal factor for subsequent behavior. Plus, I can get confirmation that these apparent instances of anger are actual instances of anger because there is a level of revelation and self-disclosure these agents are able to provide; that is, when I ask them if they are angry they can tell me. That doesn't seem possible in the god case, or if it is, again there's a qualitative dissimilarity to the way a god self-discloses the god's mental states. Of course, this isn't conclusive proof-I'm not giving an argument for atheism. I was asked for a principled basis for claiming that BFFs that generate both supernatural agent beliefs and beliefs about human minds could be unreliable in the case of supernatural agents but reliable in the case of human minds. And my answer is that human agents are empirically accessible in ways that gods, if any there be, are not; the possibility and actuality of seeing and engaging agents like Bob and Bill and Mary and John in ordinary, everyday ways, seems relevant to determining whether the BFFs are reliable in those instances. Attributing mental states to gods and attributing causal agency to gods just seems epistemologically risky in a way that doesn't seem to be the case in making similar sorts of attributions when the agent in question is Bob.

It seems like an atheist who tells a story like that is able to sufficiently meet the burden identified of explaining, in a non-ad hoc way, how her initial and prima facie justified belief in atheism, is not defeated by the standard model of CSR according to which the same BFFs are responsible for supernatural agent and mental state beliefs. 
Barrett and Church have offered what to my mind is the most compelling and sophisticated challenge to atheism based on CSR. However, Barrett and Church have not given a successful argument against atheism, and thus fail to provide any sort of indirect evidence for theism that would arise from showing that atheism is unjustified.

\section{II.B. CSR and Reformed Epistemology}

This is not to say that CSR is of no use to theists. If one is a theist, CSR should incline one to some version of Reformed Epistemology (RE). RE is a position concerning the rationality of religious belief according to which belief in God may be rational even if said belief is not formed via rational argument..$^{32} \mathrm{RE}$ is most commonly associated with its primary founder and most robust framer and defender, Alvin Plantinga. RE can be interpreted as making two general claims. The first claim is an empirical claim about how religious beliefs are often formed. The second claim is a philosophical claim about the epistemic status of those beliefs.

With respect to the empirical claim, according to RE, many religious beliefs are formed non-inferentially, or to use Plantinga's terminology, are formed in a basic way. Common examples of basic beliefs are beliefs formed via memory, sense perception, introspection, and rational insight. With respect to memory, if I ask Sue what she had for breakfast earlier that day, in the typical case Sue won't argue to the conclusion that, say, she had a bagel for breakfast. More likely she'll just remember that she had a bagel and read off that basic, non-inferred belief in response to the question. RE claims that a large set of religious beliefs are formed in a similar way, namely, as an immediate response to experience. Thus, in many cases, according to RE, people simply find themselves believing that certain things are the case with respect to God and divine agency. Oft-cited examples from Plantinga include finding oneself feeling convicted and believing that one has displeased God on the basis, not of another belief, but on the experience of, say, reading the Bible; or, perhaps one senses and believes that God forgives my sin upon praying for forgiveness. Plantinga dubs this epistemology "Reformed" because he draws in thinkers in the Reformed tradition who have been suspicious of the capacity or necessity of natural theology to prove the existence of God. Plantinga uses John Calvin's term "sensus divinitatis" or "sense of divinity" to refer to the basic belief-forming cognitive process that produces belief in God.

There's an interesting correlation between the religious epistemology Plantinga created from the comfort of his armchair four decades ago and the empirically informed CSR of the last decade. Recall that according to the standard model of CSR, belief in supernatural agents is among the

\footnotetext{
${ }^{32}$ Reformed Epistemology has been a major topic in philosophy of religion and religious epistemology for nearly four decades, and as such has generated a huge volume of literature. Seminal works here include Plantinga, "Reason and Belief in God," 16-93. See also Plantinga, Warranted Christian Belief. For Catholic responses to Reformed Epistemology, see Zagzebski, Rational Faith.
} 
cognitively natural outputs of non-reflective (i.e., basic or non-inferential) basic belief-forming cognitive systems. Similarly, according to RE, belief in God is the natural output of a basic belief-forming cognitive mechanism or sensus divinitatis. ${ }^{33}$ Empirical work in CSR has not disproved, and is consistent with, RE's claims about how beliefs in supernatural agents are formed.

If the first dimension to RE is an empirical claim about the typical cognitive processes that produce religious beliefs, the second dimension to RE is a philosophical claim about the epistemic status of beliefs produced by those cognitive processes. As a type of externalist epistemology, RE claims that in certain conditions, basic belief-forming processes can generate basic beliefs that have positive epistemic status, whether those processes generate beliefs about the past (as with memory) or beliefs about God (as with the sensus divinitatis). And if those processes are designed to be truthoriented, and successfully operating in the conditions for which they are intended, then their outputs are rational, justified, and may even satisfy conditions for knowledge.

Now, CSR doesn't prove that RE is true, because CSR doesn't make any philosophical claims about epistemic externalism in general or RE in particular. Moreover, even if one accepts CSR and accepts epistemological externalism, that wouldn't be sufficient for CSR to entail RE. This is because what further needs establishing is that the causal processes that underlie religious belief are reliable. This is, in effect, what Barrett and Church were arguing in their paper discussed above. If Barrett and Church were successful, then CSR plus epistemological externalism would establish $\mathrm{RE}$, because one would have (a) an empirically supported model of how religious beliefs are formed (establishing the first claim of RE), (b) an epistemological framework according to which reliable, properly functioning cognitive faculties are sufficient for generating rational justification, and (c) a reason for thinking that in certain conditions the cognitive processes that generate religious belief are (in certain respects) reliable. Recall that for Barrett and Church it's the same cognitive toolkit that gives us reliable information about, for example, the mental states of other agents (and a host of other belief-domains) as well as religious beliefs. They further argue that when it comes to a certain level of supernatural agent belief, these generally reliable faculties are suddenly malfunctioning. However, I've argued that Barrett and Church have not successfully defended the reliability of the cognitive processes that generate religious belief insofar as the reflective atheist is concerned..$^{34}$

\footnotetext{
${ }^{33}$ For more in depth treatment of the parallels between CSR and Reformed Epistemology, see Clark and Barrett, "Reformed Epistemology and the Cognitive Science of Religion," 174-189; see also Clark and Barrett, "Reidian Religious Epistemology and the Cognitive Science of Religion," 1-37.

${ }^{34}$ If an atheist is prima facie justified in her atheism via Credulity, an epistemological principle Barrett and Church help themselves to, CSR does not undermine that justification.
} 


\section{Conclusion}

Although often taken to the contrary, CSR does not provide evidence for atheism. If one is an atheist, what CSR does provide is a bit of "intellectual aid and comfort." But CSR doesn't provide evidence for theism, either. And if one is a theist, CSR should incline one partway toward Reformed Epistemology. ${ }^{35}$

Trinity Western University

\section{References}

Alston, William P. 1993. Perceiving God: The Epistemology of Religious Experience (Cornell University Press).

Assmann, Jan. 2004. "Monotheism and Polytheism." In Religions of the Ancient World: A Guide, edited by Sarah Iles Johnston (Harvard University Press), 17-31.

Barrett, Justin L. 2011. Cognitive Science and Theology: From Human Minds to Divine Minds (Templeton Press).

Barrett, Justin L., and Ian M. Church. 2013. "Should CSR Give Atheists Epistemic Assurance? On Beer Goggles, BFFs, and Skepticism Regarding Religious Beliefs." Monist 96: 311-324. https://doi.org/10.5840/monist201396314

Bergmann, Michael. 2006. Justification Without Awareness: A Defense of Epistemic Externalism (Oxford University Press). https://doi.org/10.1093/0199275742.001.0001

Braddock, Matthew. 2016. "Debunking Arguments and the Cognitive Science of Religion." Theology and Science 14: 268-287. https://doi.org/10.1080/14746700.2016.1191878

Clark, Kelly James, and Justin L. Barrett. 2010. "Reformed Epistemology and the Cognitive Science of Religion." Faith and Philosophy 27: 174-189. https://doi.org/10.5840/faithphil201027216

Clark, Kelly James, and Justin L. Barrett. 2011. "Reidian Religious Epistemology and the Cognitive Science of Religion." Journal of the American Academy of Religion 79: 1-37. https://doi.org/10.1093/jaarel/lfr008

Davis, Richard Brian, and W. Paul Franks. 2015. "Counterpossibles and the 'Terrible' Divine Command Deity." Religious Studies 51: 1-19.

https://doi.org/10.1017/S003441251400016X

Lemos, Noah. 2007. An Introduction to the Theory of Knowledge (Cambridge University Press). https://doi.org/10.1017/CBO9780511801525

\footnotetext{
${ }^{35}$ This paper began as my research project as a participant in a Calvin College Summer Seminar in Christian Scholarship on Cognitive Science of Religion and Christianity which was funded by the MJ Murdock Charitable Trust. Subsequent work was funded by the Templeton Religion Trust as part of the Scholarship and Christianity in Oxford "Bridging Two Cultures" grant. Special thanks to Justin Barrett who provided comments on previous versions of this paper. Thanks also to the anonymous reviewers who provided excellent and detailed comments on previous versions of this paper. I'd also like to thank my research assistants Anna Beresford and Perry Hendricks who helped prepare this manuscript for publication.
} 
Livingstone, David N. 1989. Darwin's Forgotten Defenders (Regent College Publishing).

Marsh, Jason. 2013. "Darwin and the Problem of Natural Nonbelief." The Monist 96: 349-376. https://doi.org/10.5840/monist201396316

Mawson, T. J. 2012. "On Determining How Important it is Whether or Not There is a God." European Journal for Philosophy of Religion 4: 167-177.

https://doi.org/10.24204/ejpr.v4i4.262

Murray, Michael J. 2009. "Scientific Explanations of Religion and the Justification of Religious Belief." In The Believing Primate: Scientific, Philosophical, and Theological Reflections in the Origin of Religion, edited by Jeffrey Schloss and Michael J. Murray (Oxford University Press), 168-178.

https://doi.org/10.1093/acprof:oso/9780199557028.003.0009

Murray, Michael J., and Andrew Goldberg. 2010. "Evolutionary Accounts of Religion: Explaining and Explaining Away." In The Believing Primate: Scientific, Philosophical, and Theological Reflections on the Origion of Religion, edited by Jeffery Schloss and Michael J. Murray (Oxford University Press), 179-199. https://doi.org/10.1002/9781444317350.ch36

Penner, Myron A. 2015. "Personal Anti-Theism and the Meaningful Life Argument." Faith and Philosophy 32: 325-337. https://doi.org/10.5840/faithphil201563039

Plantinga, Alvin. 1983. "Reason and Belief in God." In Faith and Rationality: Reason and Belief in God, edited by Alvin Plantinga and Nicholas Wolterstorff (University of Notre Dame Press), 16-93.

Plantinga, Alvin. 2000. Warranted Christian Belief (Oxford University Press). https://doi.org/10.1093/0195131932.001.0001

Sober, Elliott. 1981. “The Evolution of Rationality.” Synthese 46: 95-120. https://doi.org/10.1007/BF01064467

Sober, Elliott. 2008. Evidence and Evolution: The Logic Behind the Science (Cambridge University Press). https://doi.org/10.1017/CBO9780511806285

Sober, Elliott. 2013. Core Questions in Philosophy: A Text with Readings (Pearson).

Thurow, Joshua C. 2013. "Does Cognitive Science Show Belief in God to be Irrational? The Epistemic Consequences of the Cognitive Science of Religion." International Journal for Philosophy of Religion 74: 77-98.

https://doi.org/10.1007/s11153-011-9300-y

Van Eyghen, Hans. 2016. "Two Types of 'Explaining Away' Arguments in the Cognitive Science of Religion." Zygon 51: 966-982. https://doi.org/10.1111/zygo.12307

Zagzebski, Linda ed. 1994. Rational Faith: Catholic Responses to Reformed Epistemology (University of Notre Dame Press). 